DOI: https://doi.org/10.46630/phm.12.2020.40

Милица Љ. Јовановић ${ }^{1}$

Оригинални научни рад

Универзитет у Нишу

УДК 82.01

Филозофски факултет, Ниш

316.77

Примљен: 15. 3. 2020.

\title{
ПРОМОЦИЈА КЊИГЕ ROKI FOR REVER БРАНИСЛАВА МАРКОВИЋА ТОЧКА КАО ФЕНОМЕН КОМУНИКАЦИЈЕ
}

Овај рад се бави представљањем теорија рецепције и испитивањем да ли књижевни садржај писан као хумор у дијалекту у непосредном контакту са публиком, у овом случају интерпретацијом на књижевној промоцији истог, изазива осећај појачаног задовољства и смеха и тиме додатно потпомаже интеракцију и бољу комуникацију публике са делом. Предмет рада је промоција књиге Roki for rever аутора Бранислава Марковића Точка из Владичиног Хана, објављене 2019. године. У методолошком делу, примењени су квалитативни и квантитативни приступ, односно студија случаја, дубински интервју и анкета. Обрађена је, у складу са темом, и теорија о користи и задовољству. Иако је промоција књиге велики изазов у истраживачком смислу, полазне претпоставке су кроз радпотврђене. Садржај књиге, сачињен од пет драмских текстова („Савремене монокомедије у врањском говору“ писане у форми монодрама), који су претходно извођени на сценама широм Србије, а на промоцији интерпретиран од стране аутора, произвео је позитивну реакцију код аудиторијума. Жива реч изазвала је повратни одговор и готово идентичну атмосферу као и у позоришту, само пропорционалну мањем броју људи. Књига ће онима који су присуствовали промоцији, или гледали представе, бити нека врста реликвије - успомена и извор за поновно препознавање и уживање у доживаљајима главног јунака Рокија, само у писаној димензији.

Кључне речи: теорије рецепције, промоција књиге, врањски говор, хумор у дијалекту, задовољство публике

\section{1. Уводна разматрања}

Савремено доба у коме живимо све чешће пред нас поставља ограничења када је реч о задовољавању културних потреба. Препреке које постоје од раније (DRAGIĆEVIĆ ŠEŠIĆ 1996:19) у смислу недостатка времена, финансијских средстава и квалитетног програма, удаљености установа културе од места пребивалишта, неадекватних термина

${ }^{1}$ milica.zurnalista.90@gmail.com 
догађаја, недовољне информисаности од стране локалних медија, као и актуелних - погрешног коришћења друштвених мрежа као и слања нереалних слика о реалном свету путем виртуелног, мењају наше навике. Експанзија нових технологија довела је до преплитања масовних медија: једнима популарност расте, а другима опада из мноштва разлога. Услед наведених ограничења, посебно су у неповољном положају културне манифестације типа књижевних вечери и позоришних представа, као и друге специфичне форме у којима писана дела непосредно, односно уживо, комуницирају са публиком.

Циљ овог рада јесте испитивање да ли, и у ком опсегу, књижевни садржај писан као хумор у дијалекту у непосредном контакту са публиком (у позоришту - приказивањем, или у форми књиге - интерпретацијом на књижевној промоцији истог), изазива осећај појачаног задовољства и смеха, и тиме додатно потпомаже интеракцију и бољу комуникацију публике са делом - као и да ли таква форма лакше долази до читалачке публике (која разуме врањски говор), због препознавања локалног животног колорита, који доноси начин изражавања дела написаних у дијалекту.

Предмет рада је промоција књиге Roki for rever аутора Бранислава Марковића Точка из Владичиног Хана, чији драмски текстови (који у изворном смислу чине монокомедије претходно извођене на позоришној сцени, а овог пута сакупљени и преточени у форми књиге од укупно пет дела), представљају аутентични израз и оригинални пример комуникације дела са публиком путем промоције књиге, нарочито због комбинације врањског и књижевног говора, како у писању, тако и приликом непосредне интерпретације дела.

Конкретније, у првом делу рада, акценат је на ставовима познатих теоретичара медија Умберта Ека, Ханса Роберта Јауса и Ролана Барта, као и на теорији о користи и задовољству. Овај специфичан догађај обрађује ce, у другом делу рада, кроз студију случаја, затим методом испитивања уз помоћ упитника - скалера, након чега се на основу дубинског интервјуа са писцем долази до додатних релевантних података. Иако је промоција књиге велики изазов у истраживачком смислу, полазне претпоставке су кроз рад потврђене.

\section{2. Теоријски оквир истраживања}

Појам отвореног уметничког дела (opera aperta) дефинисао је Умберто Еко још 1962. године. Он је сматрао да аутор производи један у себи завршен облик, у жељи да тај облик буде схваћен онако како га је он 
Милица Љ. Јовановић

произвео. А како ће дело бити схваћено, према његовом мишљењу, зависи од многобројних фактора, као што су укус, култура, личне предрасуде.

„Аутор пружа уживаоцу дјело на довршење: он не зна тачно на који ће начин дјело бити приведено крају, али зна да ће дјело приведено крају ипак увијек бити његово дело, не неко друго, и да ће се на концу интерпретативног дијалога конкретизирати један облик који је његов облик, иако организован од неког другог, на начин који он није могао потпуно да предвиди“ (ЕКО 1965:55).

Иако је дело затворен и завршен облик, исто тако је и отворено за бројна тумачења. Да би уметничко дело уопште могло да функционише као такво, неопходан је напор посматрача, оно захтева да се прималац ангажује у тумачењу. Како прималац у чину реаговања на подстицај уметничког дела реагује уношењем властитих егзистенцијалних и емоционалних одређења, дело није изолована чињеница, одељено дистанцом од публике. „Једно умјетничко дјело је апарат који свако - подразумијевајући и његова аутора - може да употребљава како му је драго“ (ЕКО 1965:40). Задатак посматрача је да у сваком доживљају уметничког дела изнова оживљава његов оригинални облик. Еко упозорава да је реч о највећој могућој отворености дела што не може бити без одјека на рецептивни акт. Мрежа неисцрпних односа пред којим се налази реципијент апел је његовој слободној одлуци да потражи инвентиван одговор.

Термин „хоризонт (видокруг) очекивања“ употребио је у свом раду и Ханс Роберт Јаус. „У троуглу аутор-дело-публика, ова последња није тек пасиван чинилац, тек ланас пуких реакција, већ и сама представља енергију која ствара историју“ (MARICKI 1978:37). Јаус је посебно нагласио да уколико дело није прихваћено од стране читалаца, не може ни да опстане и додао да оно настаје како би задовољило укус публике. Свако дело евоцира код читаоца хоризонт очекивања, а начин на који бива или не бива прихваћено, одражава његову промену. „Теорија естетике рецепције не омогућава само да се смисао и форма књижевног дела појме у историјском развоју његовог разумевања. Она такође изискује и да се појединачно књижевно дело уврсти у његов "књижевни низ', да би се сазнало његово историјско место и историјски значај у повезаности искуства књижевности“ (JAUS 1987:73). Овај аутор хоризонт очекивања везује за дело а не за однос између дела и очекивања публике и проширује његово схватање на систем онога шта дело очекује од читаоца.

„Понашање уживања у естетичком, које истовремено представља ослобађање од и ослобађање за нешто, може се остваривати у трима равнима: кад је реч о свести која производи - у стварању света као њеног сопственог дела; кад је реч о свести која прима - у хватању могућности да се свет опази другачије, и најзад - на тај начин се субјективно искуство отвара према интерсубјективном...“(JAUS 1978:392). 
У контроверзном есеју „Смрт аутора“ (1986), Ролан Барт се супротставио схватањима да је аутору приписана моћ над текстом и да је он његов искључиви власник. Сматрао је да текст ствара читалац, који није само конзумент већ и тумач, а не аутор. Прогласио је потпуну независност текста од свега што је аутор намеравао рећи и закључио да рођење читаоца нужно подразумева смрт аутора.

„Ако са задовољством читам ову реченицу, ову повест или ову реч, то је зато што су оне биле написане у задовољству... Писати у задовољству, не обезбеђује ли ми то - мени, писцу - задовољство мог читаоца? Никако. За овим читаоцем треба да трагам, не знајући где он јесте“ (BART 2010:100). Овај аутор текст задовољства, између осталог, дефинише као онај који испуњава и баца у еуфорију, потиче из културе, не раскида са њом и везан је за угодну праксу читања. Такође, објашњава како стварање осећаја задовољства зависи од бројних фактора као што су расположење, околности и навике.

Од дефинисања појма рецепције и отвореног уметничког дела Умберта Ека, преко херменаутике и „хоризонта очекивања“ Ханса Роберта Јауса, „Смрти аутора“ Ролана Барта и његовог наговештаја о пријатности која настаје при конзумирању садржаја, долазимо до теорије користи и задовољства (used and gratification theory), која је за овај рад корисна јер је тема повезана са изазивањем појачаног осећаја задовољства и смеха.

Њоме су се бавили Бламер, Кац, Мек Квејл и други комуниколози истичући да није толико битно штаје хтео и желео да постигне комуникатор као и да се добровољан пристанак примаоца на остваривање контакта са само једним комуникатором подразумева. „Комуникациони акт је успешан само ако је у стању да обезбеди неку корист или задовољство реципијентима. У њој нема места за оне врсте комуницирања... у којима би човек стварао културу изван критеријума користи и задовољства“ (RADOJKOVIĆ \& ĐORĐEVIĆ 2005:228). У овом случају, занима нас „Шта људи чине са порукама и њиховим преносиоцима?“, а не „Шта медији чине са људима?“. Према теорији користи и задовољства, људи читају књиге и одазивају се културним догађајима попут промоција како би утолили своје потребе и жеље. Они су активна публика и поклањају пажњу ономе што њих интересује, они су иницијатори.

\section{3. Методолошки оквир истраживања}

Како бисмо направили прелаз из теоријског у методолошки део, морамо да представимо студију случаја коју ћемо у раду користити, а то 
је промоција књиге Roki for rever ${ }^{2}$ драмског писца Бранислава Марковића Точка ${ }^{3}$ из Владичиног Хана. Овај аналитички метод бирамо зато што истражујемо појаву која до сада није била предмет научног истраживања и, у складу са тим, служи открићу и има дескриптивни карактер.

Конкретно, истраживање је подразумевало квантитативни и квалитативни приступ. Када је први у питању, примењена је анкета у писаној форми, у комбинацији са техником скалирања. Према дефиницији, „публика представља хомогено јавно мњење, окупљено око заједничког предмета интересовања, опскрбљено информацијама, знањима и храброшћу за критичко расуђивање“ (JOVANOVIĆ 2005:29), али пошто се врло ретко може открити нека безусловна заједничка особина свих слушалаца, „преостаје само да се трага за оним што одликује већину присутних“" (AVRAMOVIĆ 2008:320). Дакле, квантитативни приступ повезан је са математиком, односно природним наукама, јер подразумева статистичку обраду на основу стандардизованих упитника и свођење информација на бројеве како би се утврдили ставови испитаника.

Ради допуне сазнања о датој проблематици, урађен је и дубински интервју са писцем коришћењем полуструктурисаног метода и то представља квалитативни приступ. Он спада у друштвену категорију, јер обухвата вербално и литерарно истраживање, у овом случају транскрипт разговора са аутором у текст. Међутим, овај приступ употребљен је и код питања отвореног типа у смислу допуне анкете од стране испитаника, али ту спада и студија случаја.

До комбинације ових приступа дошло је како би се формирала комплетна слика која се односи на истраживачко питање, дефинисано као општи циљ рада, уз уложени труд да се добијени одговори искористе у пуном потенцијалу.

\section{1. Студија случаја}

Књига Roki for rever састоји се од текстова који су претходно, у вишегодишњем периоду, извођени као позоришне представе на сценама широм Србије. То су: „Повраћај из Хаг”, „Путовање кроз густо грање”, „Made in Hollywood”, „Свемогућа мисија” и „Ел мудрињо”, познатије као Роки 1,2,3,4 и 5, где главни лик тумачи филмски и позоришни глумац

\footnotetext{
${ }^{2}$ Књига је објављена уз помоћ Скупштине општине Владичин Хан, пријавом на конкурс за финансирање и суфинансирање пројеката из области културе за 2019. годину, а издавач је Удружење књижевника Врања.

${ }^{3}$ Бранислав Марковић Точак је рођен 1962. године у Владичином Хану. Дипломирао је на департману за Позоришну и радио продукцију на Факултету драмских уметности у Београду 1994. године. Бави се писањем позоришних комада, режијом, продукцијом и музиком.
} 
и комичар Драган Божа Марјановић из Лесковца. Ова збирка, како их је аутор одредио „савремених монокомедија“, по форми припада монодрами - драмском делу намењеном једном извођачу (JOVANOVIĆ 1984:218) а према садржају комедији - „драмска врста, писана у стиховима или прози, у којој се помоћу комично обликованих карактера доведених у смешне ситуације, у склопу духовито компонованог заплета, изазива смех гледалаца, с тежњом да се људски недостаци и друштвене негативности уопште изложе подсмеху“ (JOVANOVIĆ 1984:162). Према жанровској подели, спада у комедију нарави и комедију ситуације.

Основни циљ промоција, које представљају маркетиншки облик дифузије културе, јесте пласирање неког дела, у овом случају књиге, у културну јавност. Као што је необичан сам догађај који обрађујемо у раду, тако је другачије од осталих и место истраживања - Кафе бар „Дневна соба“ у Нишу. Аутор је гостима, који су неколико дана позивани путем друштвене мреже „Facebook“, представио своје стваралаштво и упознао их са тематиком приче парафразирањем, читањем и импровизацијом одломака које је сматрао тренутно актуелним и најзанимљивијим. Идеја је била да се посетиоцима омогући да остваре са писцем непосреднији однос и директну комуникацију, као и да на миру, без гужве која би им ометала концентрацију, одговоре на питања из упитника која ће бити представљена у наставку рада. Промоцији књиге присуствовао је и модератор.

За књигу као и представе примарно се везује аутентичан стил изражавања, врањски говор без улепшавања, што их чини оригиналним и примамљивим публици. Ликови у комадима са којима Роки „комуницира“ говоре књижевним или неким страним језиком које он књижевно преводи како би дочарао лик саговорника, али су зато његови монолози и замишљене реплике увек у дијалекту.

У основном предочавању садржаја дела подсећамо да је Роки вечити младић, стално жељан изазова, па тако и у својим исповестима као средовечни човек често препричава љубавне догађаје и пехове које је доживео, несрећне али и срећне околности у којима су они настали. Дозу савремености и актуелности авантурама у причама дају познате личности попут Џенифер Лопез, Памеле Андерсон, Наоми Кембел, Мадоне, Кејт Винслет, Леонарда ди Каприа, Радета Шербеџије, Новака Ђоковића и многих других. Зачудност у радњи појачавају одређени фантазми и илузије, тако да Роки у својој уобразиљи често комуницира и са животињама као што су мачак Клео, камила Инес, мајмунче Коле.

„У нашем времену развијених масовних медија и електронских забава, жива уметност има оригиналну вредност, јединствену по томе што директно комуницира са публиком која сведочи о стварању уметности. 
Милица Љ. Јовановић

Особеност позоришног медија је у директном контакту са публиком“ (DUNĐEROVIĆ 1993:57).

Оно што приче у књизи разликује једну од друге јесте основни простор дешавања радње, који упућује на одређену атмосферу сваке понаособ. Управо он омогућава елементе добре комуникације на релацији аутор - извођач - публика јер, још у писаном делу, представља необично место предвиђено за боравак људи. Простор тако постаје позив за комуникацију и интеракцију са главним ликом јер је унапред предвиђен за присуство публике која је дошла са одређеним поводом. Тај комуникациони оквир у сваком од дела је различит. Када је у питању првенац „Повраћај из Хаг”, радња се одвија у провинцијском затвору у Србији 2006. године, затим следе „Путовање кроз густо грање” (2008.) у туристичкој агенцији, „Made in Hollywood” (2010.) у напуштеном биоскопу и „Свемогућа мисија“ (2012.) у још недорађеном простору спортске кладионице. На крају, радња „Ел Муд(р)иња“ (2014.) одвија се на заједничкој тераси која служи за сушење веша, чишћење тепиха као и састанке кућног савета на врху стамбене зграде. Простор тако представља предуслов за дружење на који се касније може позвати интерпретатор и оптимално га користити за неформални контакт са публиком - на представи или промоцији.

У завршном делу промоције књиге, Марковић је присутне подсетио на извођење свих представа од стране Марјановића као и на такве неформалне контакте у комуникацији с публиком, а које су још увек актуелне. Однос глумца са публиком заснован је на директној интеракцији, Роки од ње тражи цигарете и конзумира их у току представе, затим пролази кроз масу са кутијом где сакупља новац, жваке и још цигарета да подмити чуваре. Публика осећа да је део амбијента и уживљава се у причу. Атмосфера је непредвидива, а гестикулација на високом нивоу. Како је писао Бергсон (1995), комедија је игра која имитира живот и гестикулација се надмеће са речју. Роки вежба, удара у џак, демонстрира лет у авиону и како убија кокошке због птичјег грипа. Једној жени из публике даје кромпир и нож да га љушти ради помоћи у његовим свакодневним обавезама. „У гесту има и нечег експлозивног, нечег што буди нашу осећајност, спремну да се успава, и дозивајући нас тако к себи, спречава нас да ствари схватимо озбиљно. Дакле, чим се наша пажња усмери на гест а не на дело - бићемо у комедији“ (BERGSON 1995:68).

\section{2. Анкетно истраживање}

Популацију истраживања чинили су посетиоци промоције књиге Roki for rever Бранислава Марковића Точка из Владичиног Хана на узорку од 20 испитаника. Овај узорак је одговарајући због тога што је у 
питању само једна промоција и јер су због капацитета којим располаже место одржавања (до 30 места), сви могли да се „уживе“ у атмосферу. Анкетни листови подељени су им чим су заузели своја места.

За потребе истраживања конструисан је упитник ${ }^{4}$ - скалер са укупно 23 питања / тврдњи. Испитаници су на њих одговарали заокруживањем једног од понуђених одговора или допуном одговора код питања отвореног типа, а скала процене је била Ликертовог типа и подразумевала степене слагања са датом тврдњом у вредностима од 1 до 5. Упитник се састојао од 11 питања на заокруживање, 8 тврдњи и 4 питања на дописивање. У истраживању узорка коришћена је метода испитивања, која подразумева прикупљање емпиријских података посредством исказа, у овом случају писаних, од стране испитаника. За обраду података добијених истраживањем коришћена је дескриптивнанаучно-истраживачка метода. У складу са проучаваним проблемом, примењени су одговарајући статистички поступци који су омогућили приказивање добијених података и њихову анализу. Обрада података након реализације истраживања извршена је ручно, због малог узорка испитаника. Истраживање је обављено 18. јануара 2020. године. ${ }^{5}$

\section{3. Дубински интервју 6}

С обзиром на то да је већина анкетираних испитаника била шкрта на речима при попуњавању питања отвореног типа, додатно је употребљен дубински интервју са аутором промовисане књиге. Након почетне припреме и детаљнијег упознавања са његовим радом и делом, нивоом образовања, личним интересовањима као и кључним професионалним постигнућима, договорена је реализација интервјуа у једном локалном кафићу и прецизирано је да разговор траје до 45 минута. Одговори на питања снимани су диктафоном на мобилном телефону, како хватање белешки и директно писање на папиру током разговора не би одузимало на времену. Када је предвиђени рок истекао, испитаник је имао на располагању још 15 минута како би могао да дода или објасни неке значајне ствари које су кроз питања занемарена, што је и искористио. За те потребе формулисано је 9 питања и примењен је полуструктурисани метод, где је испитаник имао осећај да води целу причу, наравно уз

\footnotetext{
${ }^{4}$ Упитник коришћен у истраживању доступан је на линку апликације Google Drive: https://drive.google.com/open?id=1V1dz5Glf9ojv6yX4b6cmY6_TmPV6QeO6

${ }^{5}$ Ова књига је до сада промовисана на три локације на југу и југоистоку Србије. Пре Ниша, у Центру за културу, туризам и библиотекарство у Владичином Хану 17.10.2019. као и у сали Периодике Јавне библиотеке „Бора Станковић” у Врању 29.11.2019. године. ${ }^{6}$ Интервју у целости доступан је на линку апликације Google Drive: https://drive.google. com/open?id=1a4dtY5EWoxanBneWEkilwlYA_D4hidl5
} 
повремено преусмеравање од стране истраживача на оно што сматра битнијим у датом тренутку. Одлука за непосредан „face to face“ визуелни контакт донета је како би се приметиле потенцијалне значајне невербалне реакције на поједина питања и одговоре на иста. Разговор је обављен 22. јануара 2020. године.

\section{4. Интерпретација резултата и дискусија истраживања}

Одговори испитаника који су били обухваћени анкетом у методолошком делу, показали су да је за већину њих промоција књиге представљала упознавање и први сусрет са ликом Рокија. Дакле, ово дело је за њих било новина и концентрисали су се на садржај књиге и пишчев начин интерпретације одабраних делова.

У анализу добијених података кренуло се од социо-демографских карактеристика. Примећено је да су приближну заинтересованост за овакву врсту догађаја показали мушкарци и жене и то исте просечне старости (популација средњег доба). Најстарија испитаница имала је 85, а двоје најмлађих по 15 година. Најбројнији су били запослени, са средњом стручном спремом, неудати и неожењени, из Ниша.

Такође, на основу приказаних одговора на наведена питања и тврдње у вези са основном претпоставком овог рада, утврђено је да се она може прихватити. У прилог томе иде највиши степен слагања - потпуног задовољства испитаника са констатацијама: „Хумор у дијалекту појачава мој осећај задовољства“ (75\%), „У потпуности разумем врањски говор“ $(60 \%)$ и „Потребно им је више смеха у свакодневном животу“ (60\%). Квалитетом хумора који је понуђен у овој књизи у потпуности је задовољно више од половине испитиваног узорка (55\%).

Текстови из књиге Roki for rever извођени су као позоришне представе. Ипак, највећи број испитаника (55\%) их никада није гледао. Представе о Рокију налазе се и на друштвеној мрежи Youtube. Половина испитаника их није гледала, а нешто мањи број (40\%) јесте. Онима који су одговорили позитивно, мотив је био хумор у локалном дијалекту и говору јужне Србије (75\%), жеља за смехом као и поређење осећаја гледања уживо са оним „из фотеље“. Већина (55\%) се сложила са тврдњом „Освојила ме непосредност писца (глумца) на промоцији (у представи)“.

Комплетно попуњен упитник предала је особа женског пола (60 година, незапослена, висока стручна спрема, удата, из Ниша), која је признала да је за Рокија први пут чула на промоцији књиге, као и да се насмејала до суза: „Топли врањски дијалект, заплети и начин размишљања описују нашег обичног човека, то ми се највише допало. Допунила бих 
причу дневним политичким дилемама и судбинским питањима са којима сви живимо, јер су теме које могу да се обраде хумористично неисцрпне“. Она је истакла да је пишчев наступ доживела шармантним и духовотим и додала да ће се потрудити да другим људима пренесе своје утиске и препоручи им Рокија.

Најстарија испитаница (85 година, професорка књижевности у пензији, висока стручна спрема, удовица, из Ниша) посебно је нагласила да су јој се у прочитаним исечцима на промоцији књиге највише свидели духовитост текста, интерпретација аутора и врањски дијалект. Комплетно вече оценила је четворком уз напомену да атмосфера у кафићу омета комплетан доживљај.

Онима који су своје мишљење изнели, у већини случајева се допада врста хумора и то што је дело написано на врањском дијалекту (75\% од $60 \%$ укупног узорка). Уживо су гледали најчешће представе „Made in Hollywood“, затим „Повраћај из Хаг“ па „Путовање кроз густо грање“ и „Свемогућу мисију“, док „Ел мудрињо“ нису помињали. Као омиљене делове навели су рецепт за спреј „Роки смајл“, причу о школским данима и боравку и иностранству, као и обраду песме „Не дај се, Инес““

Неки од њихових коментара били су: „Утисак је одличан, све је забавно и интересанто“, „Свака прича држи пажњу и урнебесно је смешна на свој начин“, „Свиђа ми се дизајн корица књиге“, „Одличне комедије и сатире“, „Увек ме насмеју архаични изрази у говору“, „Допада ми се начин на који писац осликава ситуације“, „Изврстан аутор и оригиналан хумор“.

Да су им се садржај и промоција књиге Roki for rever свидели недвосмислено указују следећи параметри: нагласили су да сматрају да прича о овом лику треба да буде настављена кроз нова остварења (90\%), изразили жељу да купе примерак за себе (у већини од 50\%, неодлучно је било 40\%, незаинтересовано 10\%) и да се представе са Рокијем чешће изводе у локалном позоришту (80\%). Последње питање у упитнику подразумевало је оцену промоције књиге од 1 до 5, где је петицу дало $55 \%$, четворку 40\%, тројку и двојку нико и јединицу 5\% испитаника. Средња просечна оцена ове културне вечери износи 4,4.

У разговору са Браниславом Марковићем откривамо вишезначност симболике наслова књиге. Примарно је повезан са именом главног јунака, а наставак подсећа на енглеску фразу „forever“ (Роки заувек), но пошто се поменута реч у наслову раздваја и додају се два слова „р“ па се чита „фор ревер“, значење те кованице у преводу би било „Роки за ревер“, те се исто тумачи као жеља да лик Рокија представља симбол смеха и доброг расположења који се може закачити као „беџ на ревер“. Из тог наслова, аутор је дошао на идеју да на насловној страни корица, 
на илустрацији „ревера од капута“, буду закачени беџеви са ликом Рокија из плаката свих пет приказаних представа.

О потврди успеха дела код публике, аутор напомиње да је предност комедије та што је „фидбек“ у смислу потврде и одобравања, осим аплауза, запажен и непосредно кроз реакцију смеха који није једини, али јесте кључни параметар за општи утисак који се код публике ствара. Он инспирацију за писање прича о Рокију везује за први део књиге „Повраћај из Хаг“ и каже да је све почело када је приликом једног од живих преноса хашких суђења утишао тон на свом телевизору и схватио да му је призор који види забаван, а на моменте и смешан.

Аутор врањски говор и дијалект назива „колатералном коришћу“ окружења у којем је рођен и где живи, те апострофира на увек присутну огромну креативну сенку Врањанца Боре Станковића. Иако је овај приповедач, романсијер и један од најзначајнијих писаца српског реализма у свом великом опусу створио само неколико драма, оне су као литература оставиле значајан траг и на српској позоришној сцени представљају „велику капију“ кроз коју се треба проћи.

На основу дубинског интервјуа са писцем, потврђена је добра комуникација између аутора и публике, јер је и он стекао тај утисак. Промоција књижевног дела показала се интерактивном, као комуникацијски чин на релацијама продуцент - текст - реципијент, односно аутор - дело - читалац, а не као монолошки говор. Садржај књиге који је раније постојао само у форми позоришних представа, произвео је реакцију код аудиторијума и изазвао повратни одговор. Но, како аутор напомиње, смех није једини параметар у вредновању дела у писаној форми. Његова предност је и могућност враћања на поједине прочитане делове који у позоришту брзо прођу, тако да ће онима који су представе гледали бити нека врста реликвије, успомена и извор за поновно препознавање и уживање у доживљајима главног јунака Рокија, само у писаној димензији.

\section{5. Закључна разматрања}

Промоције се организују ради приближавања и популаризације одређеног уметничког дела или културног производа, у овом случају књиге Roki for rever. Препознавањем лика глумца Драгана Боже Марјановића на њеним корицама, људе са југа Србије цела прича везује за успомене на његова извођења Рокија на сцени. Углавном, сву „славу“ приписују њему, док је аутор увек у сенци. Циљ ове промоције био је и представљање Бранислава Марковића Точка. 
Како тренутно не постоји релевантна књижевна критика за поменуто дело, овог пута се нисмо бавили књижевним значајем, односно његовом вредношћу из угла драматургије, већ смо се осврнули на прелазак из форме позоришне представе у форму књижевног дела, као и на његов укупан феноменолошки значај у друштвеним догађајима у времену у којем се презентује. Акценат је стављен на кореспонденцију дела кроз промоцију књиге као нови, продужени облик комуникације са публиком. Потврдили смо његову перманентност у сусрету са новом публиком, степен комуникације и интеракције, и утврдили да су утисци и перцепције првенствено везани за хумор у дијалекту и реакције на смешне ситуације.

Оно што промоцију књиге као догађај суштински разликује од класичне позоришне представе су форма и начин интерпретације. Материјал је исти, реакције су предвидиве, језик је разумљив за циљну групу на којој смо применили анкету. Полазећи од претпоставке да књижевни садржај писан као хумор у дијалекту у непосредном контакту са публиком, у овом случају интерпретацијом на књижевној промоцији истог, изазива осећај појачаног задовољства и смеха и тиме додатно потпомаже интеракцију и бољу комуникацију публике са делом, на основу анализе одговора испитаника присутних на промоцији књиге као и интервјуа са аутором (представљених у претходном поглављу) долазимо до закључка да је можемо прихватити. Доказано је да таква форма лакше долази до читалачке публике (која разуме врањски говор), због препознавања локалног животног колорита, који доноси начин изражавања дела написаних у дијалекту.

Упркос неуобичајене чињенице да се промоција књиге одржала у кафићу и што су посетиоци испред себе имали аутора а не глумца, показало се да жива реч и интерпретација исечака из књиге изазивају готово идентичну атмосферу као и у позоришту, само пропорционалну мањем броју људи. Позитиван индивидуални утисак публике потврђен је у каснијем неформалном разговору, а они који у том тренутку нису били у могућности да купе књигу, информисали су се где могу накндадно да је пронађу како би са Рокијем поново успоставили конекцију и могли да конзумирају садржај кад год им се прохте. Ако се смех може доживети у себи, књига постаје његов чувар.

Лик Рокија из представа постао је нека врста иконе, код за препознавање већ познатог осећања пријатности приликом живих сусрета са глумцем, а који ће се као комуникација и добра конекција, наставити и приликом читања. То ће условити један другачији доживљај који књига, односно текстови комада у њој, дају уз много више информација и могућности индивидуалног доживљаја за сваког читаоца понаособ.

Основни предуслов постојања књиге је читалац, док је промоција најбољи начин за комуникацију аутора и дела са публиком. Но, на крају се може с правом поставити питање: Која би у вези са тим била улога 
Милица Љ. Јовановић

масовних медија? Можда би успех књижевне вечери, приказан кроз перо угледног критичара који је објављен у штампи, допринео да интересовање за наредно буде још веће. Такође, позивање потенцијалних гостију путем радија и телевизије непосредним гостовањем аутора, актера у програму, има моћ да заголица пажњу и подстакне знатижељу слушалаца и гледалаца када је у питању садржај књиге. Осим тога, масовни медији могу да популаришу књижевна остварења у смислу приказивања извештаја са разних фестивала. Добар наговештај у погледу информисања публике у последње време представља повећано коришћење интернета. Све је више издавачких кућа и центара културе који имају своје портале, тако да су заинтересовани у сваком тренутку упознати са актуелним издањима и репертоарима. Сврха медија у промовисању уметности и дифузији културе је очување старе и стварање нове публике, перманентно обавештавање о културним збивањима, што се добрим делом односи и на стално приближавање књижевног стваралаштва.

\section{Цитирана литература}

AVRAMOVIĆ 2008: AVRAMOVIĆ, Sima. Rhetorike techne : veština besedništva ijavni nastup. Beograd: Pravni fakultet Univerziteta i JP Službeni glasnik, 2008. [orig.] АВРАМОВИЋ, Сима. Rhetorike techne : вештина беседништва и јавни наступ. Београд: Правни факултет Универзитета и ЈП Службени гласник, 2008.

BART 2010: BART, Rolan. Zadovoljstvo u tekstu; čemu prethode Varijacije o pismu. Beograd: JPSlužbeni glasnik, 2010. [orig.] БАРТ, Ролан.Задовољство y тексту; чему претходе Варијаџије о писму. Београд: ЈП Службени гласник, 2010.

BERGSON 1995: BERGSON, Anri. Smeh: esej o značenju komičnog. Beograd: Lapis, 1995.

DRAGIĆEVIĆ ŠEŠIĆ \& STOJKOVIĆ 1996: DRAGIĆEVIĆ ŠEŠIĆ, Milena, STOJKOVIĆ, Branimir. Kultura-menadžment, animacija, marketing. Beograd: Klio, 1996. [orig.] ДРАГИЋЕВИЋ ШЕШИЋ, Милена, СТОЈКОВИЋ, Бранимир. Култура-менаимент, анимација, маркетинг. Београд: Клио, 1996.

DUNĐEROVIĆ 1993: DUNĐEROVIĆ, Aleksandar. Menadžment u pozorištu. Beograd: Muzej pozorišneumetnosti Srbije, 1993.

EKO 1965: EKO, Umberto. Otvoreno djelo. Sarajevo: Veselin Masleša, 1965.

JAUS 1978: JAUS, Hans Robert. Estetika recepcije; izbor studija. Beograd: Nolit, 1987. JOVANOVIĆ 2005: JOVANOVIĆ, Zoran. Komunikacijska kultura. Vranje: Učiteljski fakultet, 2005. 
JOVANOVIĆ 1984: JOVANOVIĆ, Raško. Pozorište i drama. Beograd: IRO „Vuk Karadžić“", 1984.

MARICKI 1978: MARICKI, Dušanka. Teorija recepcije u nauci o književnosti. Beograd: Institut zaknjiževnost i umetnost, 1987.

RADOJKOVIĆ, ĐORĐEVIĆ 2005: RADOJKOVIĆ, Miroljub, ĐORĐEVIĆ, Toma. Osnove komunikologije. Beograd: Fakultet političkih nauka: Čigoja štampa, 2005.

\section{Извори}

MARKOVIĆ 2019: MARKOVIĆ, Branislav. Roki for rever. Vranje: Udruženje književnika Vranja, 2019.

\section{Milica Lj. Jovanović}

\section{PROMOTION OF THE BOOK ROKI FOR REVER WRITTEN BY BRANISLAV MARKOVIC TOCAK AS COMMUNICATION PHENOMENON}

This article represents the theory of reception and examines whether literal content written as a humor and with direct contact with audience, when is interpretedon the book promotion of the same evoke greater satisfaction and laugh, increasing interaction and better communication between the audience and the book itself. The subject of a paper is the book promotion Roki for rever written by Branislav Markovic Tocak from Vladicin Han, published 2019. Methodological part contains both qualitative and quantitative approach in the form of case-study, in-depth interview and survey. Theory of audience benefit and pleasure is also addressed in accordance with the book topic. Even though, when we speak of research, a book promotion represents a great challenge, in this case starting assumptions have been confirmed. The content of the book, which is made of the five dramatic texts („Contemporary monocomedies in City of Vranje dialect" written in the form of monodramas), previously performed in theaters across Serbia, interpreted by its author on the promotion, produced positive audience reaction. The living word got great response and exact theatrical atmosphere compatible to smaller audience. For those people who attended promotion and watch plays, the book represents a relic, reminder and source for re-enjoying experience of the main character kRocy in the written dimension.

Key words: the theory of reception, book promotion, City of Vranje dialect, comical aspect of a dialect, reader satisfaction 